\title{
Building Learning Path of Mathematical Creative Thinking of Junior Students on Geometry Topics by Implementing Metacognitive Approach
}

\author{
Kms. M. Amin Fauzi ${ }^{1}$, I Wayan Dirgeyase ${ }^{1} \&$ Agus Priyatno $^{1}$ \\ ${ }^{1}$ State University of Medan (Unimed), Jl. Pasar V Medan Estate, Indonesia \\ Correspondence: Kms. M. Amin Fauzi, S State University of Medan (Unimed), J1. Pasar V Medan Estate, \\ Indonesia. E-mail: aminunimed29@gmail.com
}

Received: July 27, 2018

doi:10.5539/ies.v12n2p57
Accepted: September 15, $2018 \quad$ Online Published: January 30, 2019

URL: https://doi.org/10.5539/ies.v12n2p57

\begin{abstract}
Mathematical creative ability is one of the most important skills students must have to process the information provided in resolving the problem. Before using mathematical creative skills, prior knowledge becomes the most crucial thing that allows students to connect all existing information so that they can construct new knowledge through assimilation or accommodation processes. The process of forming mathematical concepts with metacognitive questions that might be carried out by students causes a metacognitive process in students that will affect their mathematical behavior.

The purpose of this study is to (1) analyze prior knowledge of what students miss or forget so that they have difficulty to answer the given geometry problem, (2) how the learning path of creative thinking of students with the application of metacognitive approach. This type of research is Design Research to improve the quality of learning. This type of research is research design, data collection techniques. The researcher gave 2 geometry questions to 38 8th graders selected randomly in SMP Medan city. Questions given are tailored to Cognitive level 4 (C4) for questions 1 and C5 for question 2 based on Bloom's taxonomy. Data analysis techniques are descriptive qualitative. This study shows that prior knowledge becomes important to build students' mathematical creative ability to gain new knowledge, especially in the field of geometry. The most problematic topics that make it difficult for them to understand geometry are the area of the rectangle and the cube webs. In dividing the rectangle into two equal parts, students still have not created another form of flat build or have not been able to get out of the rectangular pattern or exactly the same as the available problem.

There are five phases of learning trajectory of hierarchically creative mathematical thinking, which is orientation to problem, problem solving plan, plan realization, previous knowledge mastery / concept of mathematical creativity and evaluation of result obtained. Students do metacognition on the learning path of creative thinking in a comprehensive way from evaluation to planning, action to the formation of prior knowledge and selection of creative ideas. From these explanations, it is important that teachers need to ensure students have enough prior knowledge to make it easier to construct new knowledge, as well as to make learning fun and meaningful so that students will remember knowledge in long-term memory.
\end{abstract}

Keywords: mathematical creative ability, geometry, prior knowledge, metacognitive approach

\section{Introduction}

Thinking is a necessary thing in a process that involves manipulating and transforming information in memory. The ability to create new and original ideas in manipulating and transforming information is called creative thinking. Gardner (2004) views creativity as one of the 'multiple intelligences' that encompass a wide range of brain functions of constructing cognitive schemes. A student's cognitive level will work broadly when using creativity. The creative aspects of the brain can help explain and interpret abstract concepts, allowing children to attain greater mastery, on subjects such as mathematics, especially geometry that are often difficult to understand with regards to spatial abilities. In the process of solving mathematical problems students need to come up with creative ideas. The process of creative thinking can be seen from the perspective of Wallas' (1926) theory. Wallas in his book The Art of Thought states that the creative process includes four stages: preparation (gathering relevant information), incubation (received inspiration), and verification (testing and evaluating ideas acquired). 
Metacognitive strategies in learning that have a positive effect on the ability of creative thinking (Fauzi, 2018). In line with Borich (1996) that metacognition is a strategy to implement and monitor thinking models that involve the reasoning of learners and focus on the use of reasoning. In this case, it is clear that the focus of metacognitive strategies is the reasoning of the students to be more creative. In addition, Nur (2000) states that metacognitive relates to students' knowledge of their own thinking and their ability to use their own learning strategies and specific abilities appropriately. Therefore learners can be taught strategies to assess their own understanding, calculate how long it takes to learn something and choose an effective plan for learning or solving a problem. Based on this, it is clear that metacognitive strategies lead to use reasoning (planning many ideas of solution fit with problems, monitoring all problem solving, why I find it difficult to understand and master them and always think more than one answer and evaluate them) in solving mathematical problems. Here is an illustration of metacognitive strategies for acquiring creative thinking skills.

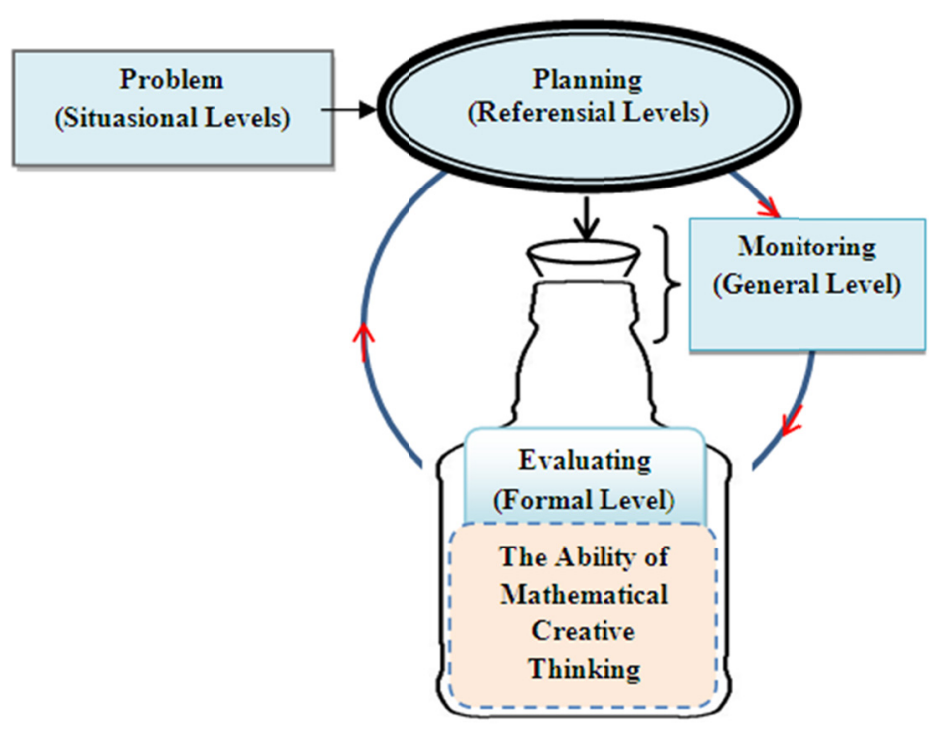

Figure 1. Illustration of metacognitive strategies for gaining the ability of creative thinking (Mutia \& Fauzi, 2017)

In this article, researchers will focus on the ability to think creatively. Creative thinking is a fundamental way in man to be able to understand mathematical ideas. Students use creative thinking as a tool to aid their mathematical abilities by building abstract mathematical ideas into more concrete minds by using logical thinking, because creative thinking is a sign or configuration of marks, characters, or objects that mark and configuration to describe, or represent something other than himself. So this will support students in learning and communicating, connecting mathematical concepts to solve problems given. From this explanation, students who have low creative thinking skills will demonstrate the ability to generate ideas, question and respond to questions or arguments that are also low.

This statement is also supported by some research results such as (Mutia and Fauzi, 2017) students tend not to be able to give a reason of the allegations given. In this case the student is only able to give a guess without being able to give the right reasons. The ability of elaboration, which is one component of creative thinking, is a key factor that stimulates students to create using their knowledge in problem-solving activities. A person without the ability to think creatively, individually difficult to develop his imaginative ability so less able to see various alternative solutions to the problem. This illustrates that creative thinking skills enable an individual to perceive a problem from multiple perspectives to enable it to find creative solutions to problems to be solved.

Prior knowledge is needed in accelerating the understanding of mathematical concepts that can be measured by how much behavioral changes that occur after a person follows the learning process. This formula indicates that Prior Knowledge is not only related to the knowledge aspect but also about attitudes and experiences that a learner has. Relating to Prior knowledge (Matsuda et al. 2013, p. 1154) has conducted research in two different procedural capabilities. The results found that prior knowledge greatly influenced the learning process. In addition, regression analysis shows that prior knowledge is the dominant facemask affecting posttest results for procedural ability testing. In addition, Chen and Huang (2013, p. 177) also found that prior knowledge affected 81 students from two different 
classes who were treated differently in the form of game-based learning systems. It is also evidenced by (Bringual et al: 2016: 2) that prior knowledge in mathematics influences interaction with learning systems and demonstration abilities. From the explanation, it can be concluded that prior knowledge is one of the most important things to build new information in the minds of students. Also there are some points that must be linked to make creative thinking of the information provided.

Geometry, an indispensable topic in mathematics, is considered a rich area to encourage problem solving and student reasoning (Jupri, 2017, p. 1). To address the problem, students need to use representations of relevant information (Krawec, 2014, p. 103). Relevant information comes from questions that can then be connected to the information in the minds of students. Information in the minds of students is closely related to their existing knowledge of so-called prior knowledge. Students will use prior knowledge to create a visual image so that new knowledge will be more readily accepted at their cognitive development level.

The level of cognitive development of students in one class is different. According Soedjadi (2007: 31) in general the development of cognitive abilities of children start with a concrete thing gradually leads to the abstract. For every child the journey from concrete to abstract can be different. Some are fast and some are slow. The fast ones may not require many stages, but for those who are not fast, it is not impossible to go through many stages. Thus, every child may require learning trajectory or different learning path. Furthermore, Soedjadi (2017) provides an illustration of the learning path (learning trajectory) as shown in Figure 2 below.

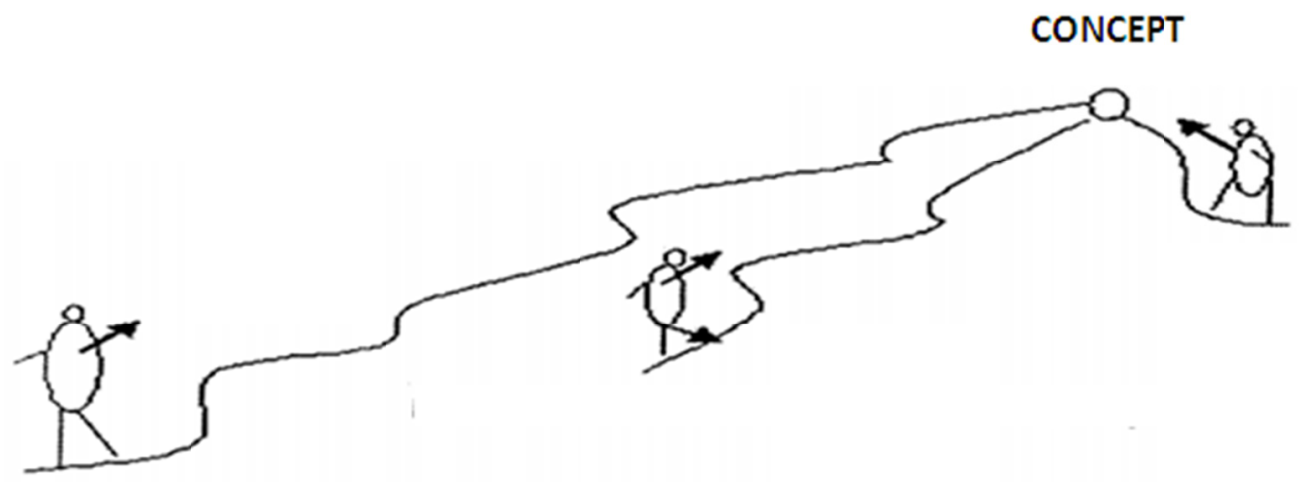

Figure 2. An illustration of the learning flow

The learning flow or better known as the learning path can help teachers in setting learning goals, and then plan the learning steps so that students can achieve the learning objectives. The importance of learning trajectory can be analogous to the planning of travel route. If we understand possible routes to the destination points, we can choose the best route to reach that destination. By knowing the learning path of the students, the teacher can design and get the proper learning path to use in helping students understand a concept.

The learning track or in English is Hypothetical Learning Trajectory (HLT). HLT consists of three components, namely learning objectives for students, learning activities and conjecture (conjecture) learning process how to anticipate students' thinking and understanding that arise in the development when learning activities are conducted in the classroom (Bakker, 2004). Simon (1995) emphasizes the HLT character of guessing how students' thinking will be formed when performing the activity and what reactions from students will occur in teaching experiments. The goal is to know the extent to which the actual learning path with the alleged trajectory has been made (Gravemeijer, 2014). This is in line with Bakker's (2004) assertion that HLT is a combination of a learning theory and an actual teaching experiment.

Based on the above explanation, the researcher analyzes what previous knowledge passed by the students so that they have difficulty in answering the questions given about geometry. How to trajectory the mathematical creative learning on the Geometry that students pass through with the metacognitive approach.

The benefit in this study is to know the previous knowledge that must be possessed by students; the teacher can design effective learning so that students do not experience failure or difficulties in building the learning trajectory to understand mathematical concepts. 


\section{Research Method}

This research uses development research with two trials as a way to answer the problem formulation so that the purpose of research is achieved. Design research is a research method that aims to develop local instruction theory through cooperation of researcher with teacher to improve learning quality (Gravemeijer \& Van Eerde, 2009). A series of student activities consisting of strategy conjectures and student thinking will be developed in this study. In this research will be designed activities based on student experience is a familiar activity for students of class VIII SMP Negeri 27 Medan as an approach to understand Geometry.

This study consists of three stages with two repetitions that can be done repeatedly until found a new theory that is the result of a revision of the experimental learning theory. Here are the steps in research design.

Stage I: Preliminary Design

At this stage a literature study of square materials and cube webs and metacognitive approaches can be established in a strategy conjecture and the path of students' mathematical creative learning. Then proceed with a discussion between the researcher and teacher about the condition of the class, the needs of research, schedule and how the implementation of research with the teacher concerned. At this stage also designed learning trajectory and hypothetical learning trajectory. Then from local instructional theory is formulated which consists of learning objectives. This conjecture aims as a guide (guide) to anticipate the strategies and thoughts of students who appear and develop in learning activities. Conjectures are dynamic and can be organized and revised during the teaching experiment.

\section{Stage II: Teaching Experiment}

In this second phase is to pilot teaching activities that have been designed in the first phase of the class. This trial aims to explore and hypothesize students' strategies and thoughts during the learning process. During the process, conjecture can be modified as a revision of local instructional theory for subsequent activities. Teachers act as teachers and researchers as the focus of observing each activity and key moments during the testing process. At this stage a series of learning activities conducted then researchers observe and analyze what happened during the learning process that took place in the classroom.

Stage III: Retrospective analysis

After testing the data obtained from the learning activities in the class were analyzed and the results of this analysis were used to plan the activities as well as to develop the design on the next learning activity. The purpose of retrospective analysis in general is to develop local level instructional theory. At this stage HLT is compared with actual student learning and from here it can answer the problem formulation. Cyclic Design Research (Gravemeijer, 2004) as follows:

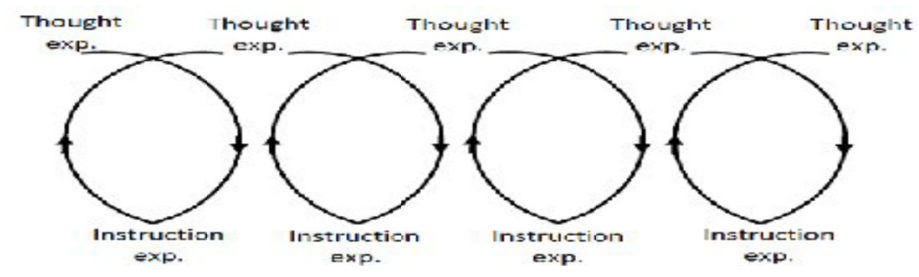

Figure 3. Cyclic process (Gravemeijer \& Cobb, 2006)

\section{Result and Discussion}

Grieshober (2004) defines creative thinking as an idea construction process that emphasizes four aspects, namely aspects of fluency, flexibility, novelty and aspects of detail. Figure 4 shows that, the improvement of each indicator of students' mathematical creative thinking ability is that in experiment I, the average ability of mathematical creative thinking on fluency indicator is 3.03 , the flexibility indicator is 3.08 , the elaboration indicator is 3.12 , and on the indicator of originality is 2.67 . In trial II, the average ability of mathematical creative thinking on the fluency indicator is 3.13 , the flexibility indicator is 3.34 , the elaboration indicator is 3.18 and the indicator of originality is 2.83 . For more details can be seen in Figure 4. 


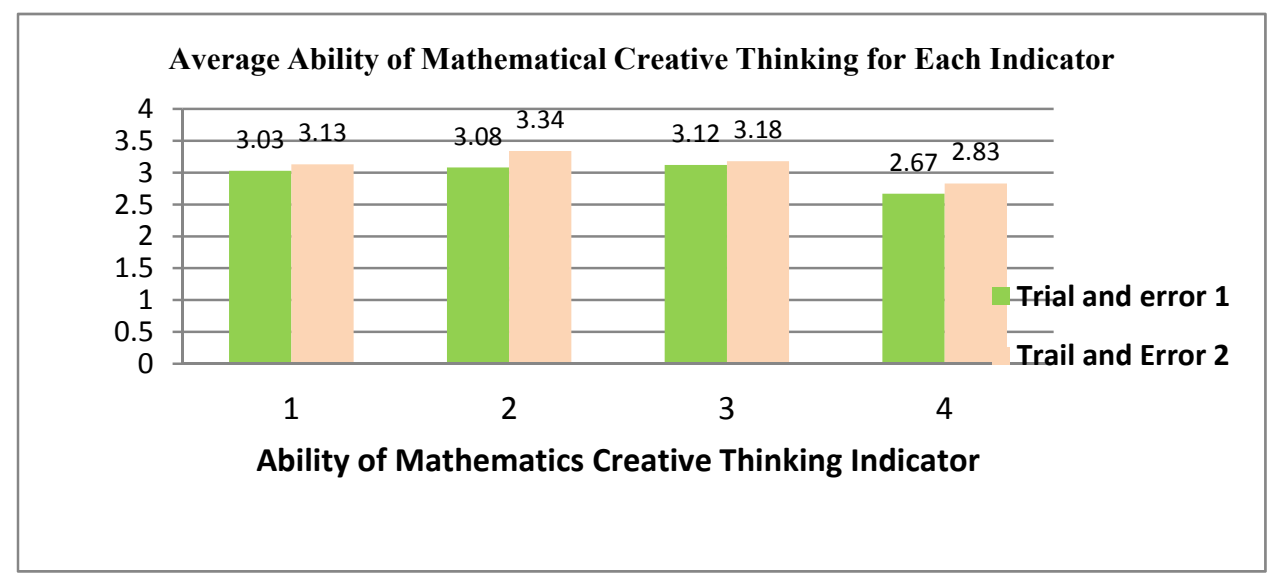

Figure 4. Average ability of mathematical creative thinking for each indicator

From Figure 4, it can be seen that there is an increase in the average of mathematical creative ability in fluency indicator of 0.10 , on flexibility indicator is 0.26 , at elaboration indicator is 0,06 , and at indicator of originality equal to 0,16 . This shows the students' mathematical creative thinking ability using learning tools developed based on metacognitive approach has increased from trial I to trial II. Here is an example of the problem and completion of the students in Table 1 below. 
Table 1. Examples of problems and solutions for creative thinking an approach to understanding geometry

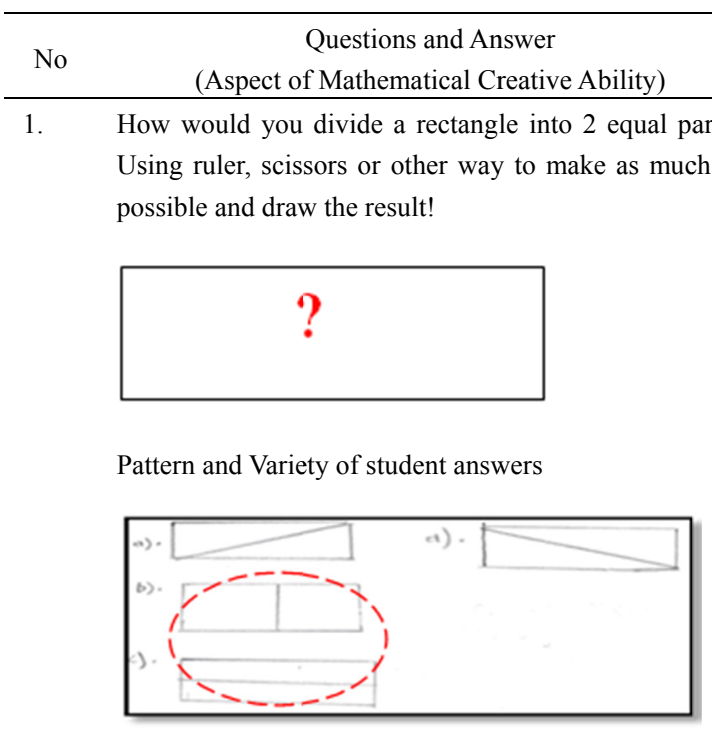

In part answer b) and c) a flat wake image that is still fluency. Students still divide the rectangle into 2 equal rectangular sections or shapes and sizes, done in 2 ways, i.e dividing papers horizontally and vertically or folded. Students are still not creative or can not get out of the existing flat pattern. Students can not be separated from the shape and the picture of the flat wake up is exactly the same as the problem available.

Pattern and Variety of student answers

In part answer b) and c) a flat wake image that is still fluency. Students still divide the rectangle into 2 equal rectangular sections or shapes and sizes, done in 2 ways, ie dividing paper paper horizontally and vertically or folded. Students are still not creative or can not get out of the existing flat pattern. Students can not be separated from the shape and the picture of the flat wake up is exactly the same as the problem available.

While the answers to parts a) and d) The division of the rectangle into 2 parts of three equilateral spans or the shape and size of which are not only fluency but flexibility by way of folding or cutting the rectangular diagonal corners opposite.

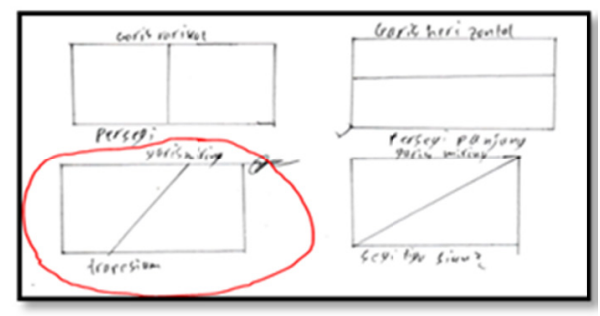

Another finding is the rectangular division into 2 equal trapezoidal sections, shapes and sizes, done in 2 ways, ie folding or dividing the paper at an angle, students can already be creative even though they do not have the value of kebaharuan. Students are able to exit or no longer follow the available flat wake drawings.
No

Questions and Answer

(Aspect of Mathematical Creative Ability)

2. Draw the cube webs, with the help of the following 2 square pieces.

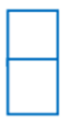

Variety of student answers

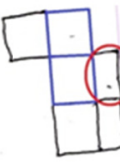

(a)

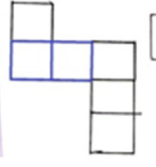

(b)

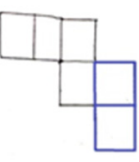

(c)
Errors found: (a) The student misplaced a square around the image. So that the net does not form a cube. From the answers (b) and (c) it appears that the student is not careful to check whether the webs are drawn correctly or not. Because when folded according to the ribs, the cube formed will have one double side, while the other side is empty.

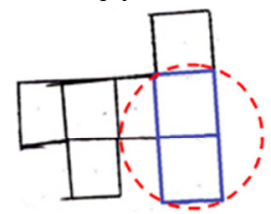

(d)

Another finding part (d) is that students draw 7 squares on the webs. Whereas the cube consists of only 6 square sides. This results in the cube being formed having one double side.

Based on the findings of students' creative thinking ability on the material of the cube nets is still hampered by the lack of mathematical reasoning of the students while verifying the answers already made.

This can be seen from the answers of students trying to find the cube nets with the original form, the students have passed the stage of illumination. But do not thoroughly check the answer according to reality. Of the total test results, the maximum number of different cube nets can be found by students per individual of 8 pieces. But when viewed from all student answers, the entire cube nets can be found all, ie 11 pieces. But the eleven cubes of the cube were found by different students. 
This study consists of three stages with two repetitions that can be done repeatedly until found a new theory which is the result of a revision of the experimental learning theory. Here are the steps in research design.

\section{Phase I: Preliminary Design}

At this stage a literature study of square materials and cube webs and metacognitive approaches can be established in a strategy conjecture and the path of students' mathematical creative learning. Then proceed with a discussion between the researcher and teacher about the condition of the class, the needs of research, schedule and how the implementation of research with the teacher concerned. At this stage also designed learning trajectory and hypothetical learning trajectory. Then from local instructional theory is formulated which consists of learning objectives. This conjecture aims as a guide (guide) to anticipate the strategies and thoughts of students who appear and develop in learning activities. Conjectures are dynamic and can be organized and revised during the teaching experiment.

\section{Stage II: Teaching Experiment}

In this second phase is to pilot teaching activities that have been designed in the first phase of the class. This trial aims to explore and hypothesize students' strategies and thoughts during the learning process. During the process, conjecture can be modified as a revision of local instructional theory for subsequent activities. Teachers act as teachers and researchers as the focus of observing each activity and key moments during the testing process. At this stage a series of learning activities conducted then researchers observe and analyze what happened during the learning process that took place in the classroom.

\section{Stage III: Retrospective Analysis}

After testing the data obtained from the learning activities in the class were analyzed and the results of this analysis were used to plan the activities as well as to develop the design on the next learning activity. The purpose of retrospective analysis in general is to develop local level instructional theory. At this stage the HLT is compared to the students' creative learning path points as the findings of this research are 5 points of the path, i.e. problem orientation, problem solving plan, plan realization, previous knowledge mastery / mathematical creativity concept and evaluation of the results obtained. Students do metacognition on the learning path of creative thinking in a comprehensive way from evaluation to planning, action to the formation of prior knowledge and selection of creative ideas.

This finding is in line with Osbon (1953) developing seven stages of the creative thinking process: orientation, preparation, analysis, ideas, incubation, synthesis, and evaluation. This means that the orientation to the problem as the starting point of the learning path of students' creative mathematics on the findings of this research is in line with Osbon's (1953) opinion that someone doing problem orientation at the stage of the creative thinking process is the first step in the introduction of the problem. In addition, the researchers found that students metacognition activities in line with the opinion Schoenfeld (1992) states that there are 3 ways to do metacognition in learning mathematics, namely belief or intuition, knowledge of thought processes, and self-awareness in the independence of learning. One's beliefs influence the problem solving of mathematics in building a way / strategy to solve the problem. Knowledge of the thinking process refers to how effectively one uses his thinking process, while consciousness itself refers to the accuracy of a person in preparing what to do in solving math problems.

When students are able to design, monitor, and reflect their learning process consciously, in essence they will become more confident and more independent in learning. Learning independence is a private possession for students to continue their long journey in meeting intellectual needs. The teacher's job is to develop the metacognitive ability of all students as a learner, without exception.

The concept of metacognition is the idea of thinking about the mind to oneself. Includes an awareness of what a person knows (metacognitive knowledge), what a person can do (metacognitive skills) and what one knows about his own cognitive abilities (metacognitive experiences). Metacognitive ability is a knowledge procedure. This is what a person deliberately does to control cognition.

Gravemeijer and van Eerde (2009) argue that students should provide opportunities to build and develop their ideas and thoughts when constructing mathematics. Educators can choose appropriate learning activities as a basis to stimulate students to think and act when constructing mathematics. In the process of the activity, the educator must anticipate any mental activity that arises from the student by still paying attention to the purpose of learning, imagery and anticipation is called Hypothetical Learning Trojectory (HLT).

Actually the whole concept of mathematics has been learned since they sat in elementary school and the characteristics of mathematics are continuous learning. So actually in some concepts, reviews remember waking flat square, constructing six square pieces into a wake-up space, and mentioning objects that resemble cubes in 
everyday life.

But in reality they also do not really understand this math concept. The researcher then conducted an interview with a mathematics teacher at the school and found that he thought geometry was the most difficult material to understand. For the topic of geometry itself, students find it hard to imagine the position of points, lines and spaces in space and to relate the information provided and understand the problem itself. According to the researcher, this can actually happen because they do not have enough prior knowledge to be able to connect information, process it, and represent the given problem so that it can be reflected in their mind until finally students can understand the purpose of the given problem. Also have a shadow of how to do the problem.

Before students recognize the difference between cube nets and non-cube nets students are trained to make cube nets. The preceding knowledge that the student must possess is square and its properties by giving examples and non-square instances, then cubes and their properties after the students understand continued with the introduction of cube nets and so on. The full path can be seen in Table 2 below:

Table 2. Hypothetical learning of cube net

\begin{tabular}{|c|c|c|c|c|c|c|}
\hline Period & Period 1 & Period 2 & Period 3 & & Period 4 & Period 5 \\
\hline Topic & \multicolumn{6}{|c|}{ Cubes and Cubes Net } \\
\hline Subtopic & $\begin{array}{l}\text { Square and } \\
\text { kinds }\end{array}$ & Cubes and kinds & $\begin{array}{c}\text { Introduction of the } \\
\text { Cube Net }\end{array}$ & & Creating Cube Nets & $\begin{array}{l}\text { Recognizing the } \\
\text { difference between } \\
\text { cube webs and } \\
\text { non-cube nets }\end{array}$ \\
\hline Meeting & $\mathrm{I}$ & II & III & & IV & $\mathrm{V}$ \\
\hline \multirow{4}{*}{$\begin{array}{c}\text { Learning } \\
\text { Activity } \\
\text { Plan }\end{array}$} & $\begin{array}{c}\text { Review } \\
\text { considering the } \\
\text { square wake }\end{array}$ & $\begin{array}{l}\text { Constructing six } \\
\text { square pieces } \\
\text { into a space }\end{array}$ & $\begin{array}{c}\text { Mentioning objects } \\
\text { that resemble } \\
\text { cubes in everyday } \\
\text { life }\end{array}$ & \multirow{4}{*}{$\begin{array}{l}\text { 1) } \\
\text { 2) } \\
\text { 3) } \\
\text { 4) }\end{array}$} & \multirow{4}{*}{$\begin{array}{l}\text { Find the cube nets } \\
\text { with 1-4-1 pattern } \\
\text { Find the cube nets } \\
\text { with } 2-3-1 \\
\text { Find the cubes webs } \\
\text { with pattern } 2-2-2 \\
\text { Find the cube nets in } \\
\text { 3-3 patterns 3-3 } \\
\text { Finding new cube } \\
\text { webs (if any) }\end{array}$} & \multirow{4}{*}{$\begin{array}{l}\text { Distinguishing which } \\
\text { are the cube webs anc } \\
\text { which are not the } \\
\text { cube nets based on } \\
\text { their properties }\end{array}$} \\
\hline & $\begin{array}{c}\text { Understanding } \\
\text { the meaning of } \\
\text { square }\end{array}$ & $\begin{array}{l}\text { Understanding } \\
\text { the sense of } \\
\text { waking up and } \\
\text { knowing the } \\
\text { name of the wake }\end{array}$ & $\begin{array}{l}\text { Understanding the } \\
\text { meaning of the } \\
\text { cube webs }\end{array}$ & & & \\
\hline & $\begin{array}{l}\text { Mention the } \\
\text { properties of a } \\
\text { square }\end{array}$ & $\begin{array}{c}\text { Mention these } \\
\text { properties }\end{array}$ & $\begin{array}{l}\text { Understanding the } \\
\text { properties of the } \\
\text { cube webs }\end{array}$ & & & \\
\hline & $\begin{array}{c}\text { Mention the } \\
\text { square elements }\end{array}$ & $\begin{array}{l}\text { Mention the } \\
\text { elements }\end{array}$ & $\begin{array}{l}\text { Knowing how to } \\
\text { make cube nets }\end{array}$ & & & \\
\hline
\end{tabular}

Before the students assigned to solve the problems associated with the properties of rectangles, students should understand it in advance with real objects or drawing a rectangle with the mention of anything that is in the rectangle so that it is students understand the sense of the rectangle. Any point in the creative learning path should be passed students to solve the problem by finding creative solutions to mathematics. To know every path of creative thinking can be viewed from the characteristics/behaviors of students when learning activities taking place, for example, students always want to get solutions to problems encountered, like to get ideas of mathematics and would like to browse what information know and asked the question. The points of the trajectory of the complete creative learning in Learning Trajectory serve at Table 3 here. 
Table 3. Learning trajectory the rectangle topic for grade viii at junior high school

\begin{tabular}{|c|c|c|c|c|c|c|c|c|c|}
\hline Period & & Period-1 & & Period-2 & & Period-3 & & Period-4 & Period 5 \\
\hline Topic & & & & & & Rectangle & & & \\
\hline Sub Topic & & $\begin{array}{l}\text { Understand } \\
\text { definition of the } \\
\text { rectangle }\end{array}$ & & $\begin{array}{l}\text { Inderstand kinds } \\
\text { of the rectangle }\end{array}$ & & $\begin{array}{l}\text { Understand kinds } \\
\text { f the rectangle by } \\
\text { picture }\end{array}$ & & $\begin{array}{l}\text { dentifying kinds of the } \\
\text { ectangle and using to } \\
\text { determine } \\
\text { ircumference and area }\end{array}$ & $\begin{array}{l}\text { Solve a related } \\
\text { problem in applying } \\
\text { the rectangle properties } \\
\text { determine the } \\
\text { circumference and area }\end{array}$ \\
\hline $\begin{array}{c}\text { Many } \\
\text { meetings }\end{array}$ & & Meeting 1 & & Meeting 2 & & Meeting 3 & & Meeting 4 & Meeting 5 \\
\hline \multirow{3}{*}{$\begin{array}{l}\text { Plan the } \\
\text { Learning } \\
\text { Activities }\end{array}$} & 1 & $\begin{array}{l}\text { Observe the } \\
\text { images or } \\
\text { objects in the } \\
\text { classes that are } \\
\text { rectangular. }\end{array}$ & 1 & $\begin{array}{l}\text { Review from: } \\
\text { The sides, } \\
\text { corners, and } \\
\text { diagonal. }\end{array}$ & 1 & $\begin{array}{l}\text { Review from: } \\
\text { The sides, } \\
\text { corners, and } \\
\text { diagonal. }\end{array}$ & 1 & $\begin{array}{c}\text { Lower } \\
\text { circumference } \\
\text { formula and the } \\
\text { area of a rectangle. }\end{array}$ & $\begin{array}{c}\text { Identify } \\
\text { problems related to } \\
1 \text { the circumference } \\
\text { and the area of a } \\
\text { rectangle. }\end{array}$ \\
\hline & 2 & $\begin{array}{c}\text { Draw a } \\
\text { rectangle }\end{array}$ & 2 & $\begin{array}{c}\text { Review from: } \\
2 \text { swivel and } \\
2 \text { symmetry } \\
\text { the } \\
\text { symmetry. }\end{array}$ & 2 & $\begin{array}{l}\text { Review from: } \\
2 \text { swivel and } 2 \\
\text { symmetry the } \\
\text { symmetry. }\end{array}$ & 2 & $\begin{array}{l}\text { Applying the } \\
\text { formula to the } \\
\text { circumference and } \\
\text { the area of a } \\
\text { rectangle based on } \\
\text { the image } \\
\text { rectangle. }\end{array}$ & $\begin{array}{l}\text { Looking closely at } \\
\text { the problems } \\
\text { associated with } \\
2 \text { application of the } \\
\text { circumference and } \\
\text { the area of a } \\
\text { rectangle. }\end{array}$ \\
\hline & 3 & $\begin{array}{c}\text { Describes } \\
\text { definition of a } \\
\text { rectangle }\end{array}$ & 3 & $\begin{array}{l}\text { Review from: } \\
4 \text { ways to be } \\
\text { paired to } \\
\text { occupy their } \\
\text { frames. }\end{array}$ & 3 & $\begin{array}{l}\text { In terms of: } \\
4 \text { ways to } \\
\text { paired } \\
\text { occupy } \\
\text { the frame. }\end{array}$ & 3 & $\begin{array}{l}\text { Calculate the } \\
\text { circumference and } \\
\text { the area of a } \\
\text { rectangle }\end{array}$ & $\begin{array}{c}\text { Solving real related } \\
\text { round-and wide } \\
\text { rectangle. }\end{array}$ \\
\hline
\end{tabular}

\section{Conclusion}

In answering the question of dividing rectangles into two equal parts, all students can provide answers to fluency, flexibility, elaboration and originality. But the ability of students to provide many answers to each indicator of creative thinking varies. The ability of mathematical creative thinking that students have is not a single ability to solve the problem of dividing a rectangle into 2 equal parts and drawing cube nets. Other capabilities such as the ability to draw a flat building connect the concept of flat building with other sciences, aesthetic values of flat-build images; suspect the broad similarity of two flat wakes and the ability to intuit mathematical concepts. There are five phases of learning trajectory of hierarchically creative mathematical thinking, which is orientation to problem, problem solving plan, plan realization, previous knowledge mastery/concept of mathematical creativity, and evaluation of result obtained. Students do metacognition on the learning path of creative thinking in a comprehensive way from evaluation to planning, action to the formation of prior knowledge and selection of creative ideas.

From these explanations, teachers should also help ensure students have enough prior knowledge to make it easier to build new knowledge, as well as to make learning fun and meaningful so that students will remember knowledge in long-term memory. For the next researcher is how to build their previous knowledge that can support the learning of geometry in accordance with the time given in the learning process.

\section{Acknowledgements}

This research is funded by Directorate of Research and Community Service, Ministry of Research Technology and Higher Education Directorate General of Research and Development Reinforcement.

\section{References}

Borich, G. D. (1996). Effective Teaching Methods (3rd ed.). New Jersey: Prentice Hall.

Bringula, R. P., Basa, R. S., Dela Cruz, C., \& Rodrigo, M. M. T. (2016). Effects of prior knowledge in mathematics on learner-interface interactions in a learning-by-teaching intelligent tutoring system. Journal of Educational Computing Research, 54(4), 462-482. https://doi.org/10.1177/0735633115622213

Chen, S. Y., \& Huang, P. R. (2013). The comparisons of the influences of prior knowledge on two game-based 
learning systems. Computers \& Education, 68, 177-186. https://doi.org/10.1016/j.compedu.2013.05.005

Fauzi, Amin M, (2018). Mathemtics Learning by Using Metacognitive Approach to Improve Mathematical Logical Thinking Ability and Positive Attitute of Junior High School Students. Journal of Education and Practice, 9(6).

Gardner, H. (2004). A Multiplicity of Intelligences: In Tribute to Pofesor Luigi Vignolo. Sceintific American, 11.

Gravemeijer, K., \& Van Eerde, D (2009). Design Research as a Means for Building a Knowledge Base for Teaching in Mathematics Education. The Elementary Shool Journal, 109(5), 510-524. https://doi.org/10.1086/596999

Grieshober, W. E. (2004). Continuing a Dictionary of Creative Term and Definition. Buffalo State Colllege: The International Center for Studies in Creativity.

Jupri, A. (2017). From geometry to algebra and vice versa: Realistic mathematics education principles for analyzing geometry tasks. In AIP Conference Proceedings (Vol. 1830, No. 1, p. 050001). AIP Publishing. https://doi.org/10.1063/1.4980938

Krawec, J. L. (2014). Problem representation and mathematical problem solving of students of varying math ability. Journal of Learning Disabilities, 47(2), 103-115. https://doi.org/10.1177/0022219412436976

Matsuda, N., Yarzebinski, E., Keiser, V., Raizada, R., Cohen, W. W., Stylianides, G. J., \& Koedinger, K. R. (2013). Cognitive anatomy of tutor learning: Lessons learned with SimStudent. Journal of Educational Psychology, 105(4), 1152. https://doi.org/10.1037/a0031955

Mutia, \& Fauzi, A. (2017). An Analysis of Students' Mathematical Reasoning Ability using Metacognitive Strategy Based-Learning in Malay Culture among Junior High School Students. Journal of Education and Practice, 8(21).

Nur, M. (2000). Strategi-Strategi Belajar. Surabaya: Pusat Studi Matematika dan IPA Sekolah.

Simon, M. A. (1995). Reconstructing Mathematics Pedagogy from A Constructivist Perspective. Journal for Research in MathematicsEducation, 26, 114-145. https://doi.org/10.2307/749205

Soedjadi, R (2007). Masalah Kontekstual Sebagai Batu Sendi Matemaika Sekolah. Pusat Sains dan Matematika Sekolah UNESA, Surabaya.

Wallas, G. (1926). Art of Thought. New York: Harcourt, Brace and Company.

\section{Copyrights}

Copyright for this article is retained by the author(s), with first publication rights granted to the journal.

This is an open-access article distributed under the terms and conditions of the Creative Commons Attribution license (http://creativecommons.org/licenses/by/4.0/). 